\title{
Perspectives On Psychotherapy: In Our Evolving Profession
}

Susan M. Hall, M.D.

Thomas Jefferson University

Follow this and additional works at: https://jdc.jefferson.edu/jeffjpsychiatry

Part of the Psychiatry Commons

Let us know how access to this document benefits you

\section{Recommended Citation}

Hall, M.D., Susan M. (1993) "Perspectives On Psychotherapy: In Our Evolving Profession," Jefferson Journal of Psychiatry. Vol. 11 : Iss. 1 , Article 14.

DOI: https://doi.org/10.29046/JJP.011.1.006

Available at: https://jdc.jefferson.edu/jeffjpsychiatry/vol11/iss1/14

This Article is brought to you for free and open access by the Jefferson Digital Commons. The Jefferson Digital Commons is a service of Thomas Jefferson University's Center for Teaching and Learning (CTL). The Commons is a showcase for Jefferson books and journals, peer-reviewed scholarly publications, unique historical collections from the University archives, and teaching tools. The Jefferson Digital Commons allows researchers and interested readers anywhere in the world to learn about and keep up to date with Jefferson scholarship. This article has been accepted for inclusion in Jefferson Journal of Psychiatry by an authorized administrator of the Jefferson Digital Commons. For more information, please contact: JeffersonDigitalCommons@jefferson.edu. 


\title{
Book Reviews
}

\section{Perspectives On Psychotherapy In Our Evolving Profession}

\author{
MOMENTS OF ENGAGEMENT: INTIMATE PSYCHOTHERAPY \\ IN A TECHNOLOGICAL AGE \\ Peter D. Kramer, M.D. \\ W.W. Norton \& Co. \\ 1989, Hardcover, 260 pp., $\$ 24.95$
}

\section{Susan M. Hall, M.D.}

In a successful attempt to describe how the evolving psychiatrist flexibly meets with immediacy the mixture of patient needs utilizing the various tools of our trade within a changing profession, Dr. Kramer presents us with Moments of Engagement: Intimate Psychotherapy In A Technological Age. The book is an outgrowth of his monthly column, "Practicing" in the Psychiatric Times in which he expresses "what it is like to practice in the profession today." The intended audience is individuals within the healing professions as well as any individual interested in psychotherapy and psychiatry. As I begin my psychiatry residency after serving patients as an ophthalmologist in private practice, I found Dr. Kramer's book enlightening, insightful and enjoyable.

The book consists of stories relating the author's work with patients. He draws on the experiences of medical school, residency, recent years in practice, and his psychoanalysis. The twelve chapters are divided into three sections entitled Moments of Engagement, Tools of the Trade, and Ambiguous Profession, consisting of four, six and two chapters respectively. This is followed by a section of notes organized chapter by chapter in which the main content of the book is embellished by references as well as the author's personal commentary.

The first section, Moments of Engagement, comprises approximately one-sixth of the book. It serves as an engaging introduction by revealing in its brief chapters, the moments of first contact between patient and therapist, or in our case, between author and reader. This sets the stage for the real work of the book contained in its last two sections.

Each chapter in Tools of the Trade begins with a vignette serving as groundwork for discussion of an important psychiatric tool, namely medication, stratagem, interpretation, support, empathy and eclecticism. Dr. Kramer's writing makes patients come alive on the page. His discussions are broad, creative, thorough and 
thought provoking. Much can be learned from these pages. I particularly enjoyed the chapters on interpretation, supportive therapy and eclecticism.

Interpretation was discussed from both the therapist and patient perspective. While the therapist may view interpretation as a tool that unites present anxiety, past trauma and current transference with insight as a goal, some patients experience interpretation as support, which may or may not lead to insight. Interpretation functioning as support can carry powerful messages to patients one would not consider psychologically minded. Such messages include: "You are important, you are acceptable and even though your actions are incomprehensible to you, they can be made sense of by someone else." The therapist's use of interpretation for purposes other than insight broadens my appreciation of this tool.

The challenges of supportive therapy highlighted in comparison to dynamic therapy enhanced my understanding of both. The less planful nature of supportive therapy coupled with the fact that patients who required the most support are uncomfortable to be with was illustrated by way of clinical example. Factors common to all therapies-respect, warmth, and empathy-were emphasized and the latter thoughtfully elaborated upon.

Eclectic psychotherapy is viewed as an integrated therapy as opposed to varying a therapy from a rigid standard, choosing among discrete therapies depending on patient type, or using different approaches in different phases of therapy with a given patient. Integrated therapies arise from an admixing of theories and techniques from different schools of thought turning their elements into new therapies tailored for the individual patient. The technique of improvisation and integrated models of care are viewed as essential.

The third and final section of the book, Ambiguous Profession, attempts to define psychotherapy. Although the term resists definition, the attempt to define what it is and what it is not, broadens my understanding of its scope and the various contexts in which it can occur.

Moments of Engagement: Intimate Psychotherapy In A Technological Age is a well written, enjoyable and insightful account of Dr. Kramer's work with patients in which he demonstrates the need to flexibly meet patients with immediacy, realizing they possess a mixture of needs. He defines the roles of the tools of our trade, while acknowledging uncategorized professional skills in a changing profession in which the therapist continues to evolve. This book is highly recommended to anyone interested in psychotherapy regardless of background, level of training or expertise. 